\title{
Penyagolosa Trails: From Ancestral Roads to Sustainable Ultra-Trail Race, between Spirituality, Nature, and Sports. A Case of Study
}

\author{
Dolores Botella-Carrubi ${ }^{1, * \mathbb{C}}$, Rosa Currás Móstoles ${ }^{2}$ and Maria Escrivá-Beltrán ${ }^{3}$ (i) \\ 1 Departamento de Organización de Empresas, Universitat Politècnica de València, 46022 València, Spain \\ 2 Department of Languages, Universidad Católica de Valencia San Vicente Mártir, 46003 València, Spain; \\ rosa.curras@ucv.es \\ 3 Department of Economics, Universidad Católica de Valencia San Vicente Mártir, 46003 València, Spain; \\ maria.escriva@ucv.es \\ * Correspondence: dbotella@omp.upv.es
}

Received: 15 October 2019; Accepted: 20 November 2019; Published: 22 November 2019

\begin{abstract}
The organization of an open-air sporting event involves a series of challenges. People are drawn by the desire to do sport, preferably in close contact with nature, so as to complement healthy lifestyles, and in search of air purity. Sporting organizations are increasingly searching for new locations that do not only attract athletes, but spectators and companions too. Races in natural parks provide the additional benefit of doing sport in a unique space, usually a transmitter of simplicity, pure air, and tranquillity. Organizing a mountain race in a natural park implies some issues. These are areas of great environmental richness that must be protected. Natural parks are places of individual recreational activity. Within the running phenomenon, a new type of mountain race has appeared: the hiking-oriented pilgrimage, in which athletes travel ancestral paths, pilgrimage routes thus combining sport practice with spirituality. This paper aims to analyse all the actions and policies that were carried out for the peaceful integration and coexistence of two totally different events that coincide physically and temporally: the Penyagolosa Trails race, and the Peregrins de les Useres, an ancestral pilgrimage that is carried out by each and every one of the towns belonging to the Penyagolosa Natural Park. The objective is to demonstrate the sustainability of the project thanks to the collective effort and the goodwill of the interested parties, in a way that produces a mutual benefit.
\end{abstract}

Keywords: sports tourism; sustainable tourism; pilgrimage; natural park; heritage; rural tourism

\section{Introduction}

The International Trail Running Association (hereafter ITRA) [1] defines trail running as: "a sport that takes place amid nature, and with respect for the environment, a sense of humility, shared community and a strong sense of sports ethics. Trail running benefits from a definition that is shared internationally by all participants".

Despite the fact that there is no clear definition of nature sports in the academy [2,3], trail running could be included in this group because it is practiced on mountain paths located in natural spaces and, exceptionally, in protected areas of high natural and ecological value, such as the Penyagolosa Park, in Spain.

In the last years, trail runners and trail races have grown significantly around the world $[2,4,5]$. The ITRA database shows that in 2007, the first year with published data, there were 142 races in the world. This number increased to 2510 in 2019. In the case of Spain, in 2007 there were only 13 trail races. This figure was boosted to 230 in 2019, which means eighteen times more races than in 2007. Figures 1 
and 2 and Table 1 show the evolution of the number of trails registered by ITRA. This phenomenon has aroused great interest among scholars in different fields and perspectives beyond sport, from medicine to philosophy through economy, local development or tourism, even drawing special attention to the relationship between sport and heritage as a generator of tourism from several perspectives [6,7].

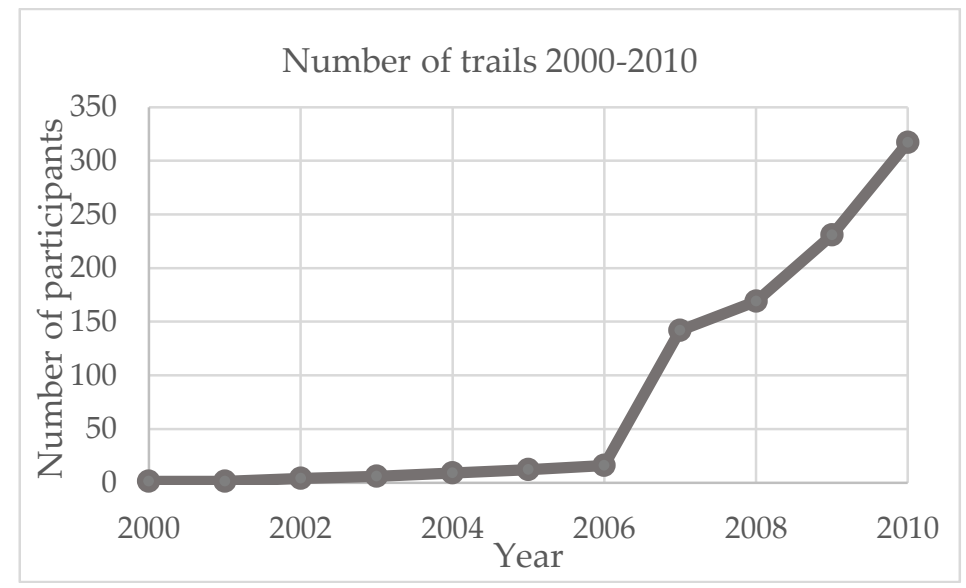

Figure 1. Number of trails, 2000-2010 [4].

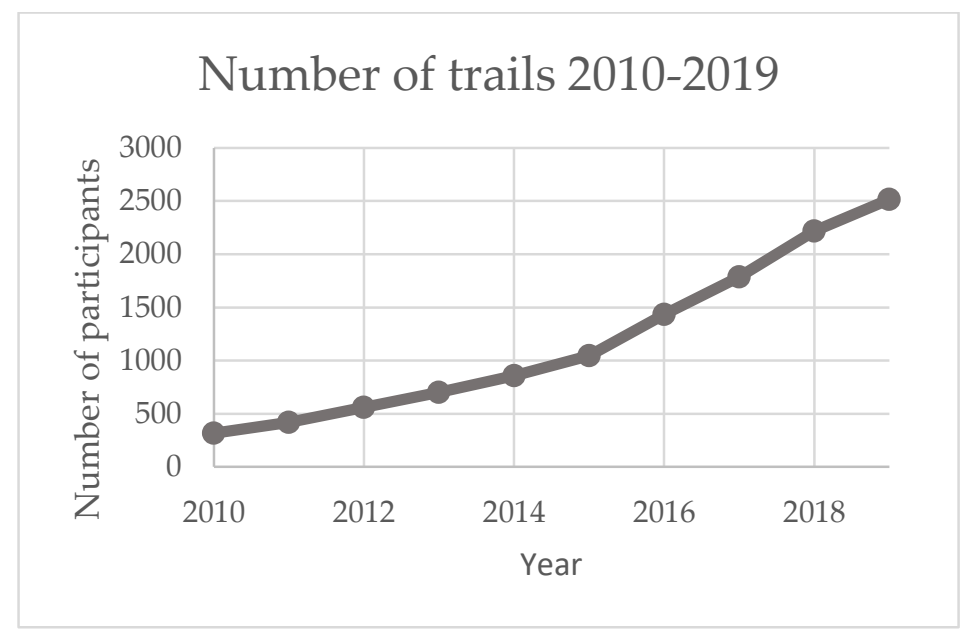

Figure 2. Number of trails, 2010-2019 [4].

UNESCO defines [8] heritage as "our legacy from the past, what we live with today, and what we pass on to future generations". In this vein, ways of connecting with the past would be diverse aspects such as sport halls of fame, museums, visiting sports stadia and sporting venues, which are places as expressions of cultural identity or nostalgia. This has been referred to as secular pilgrimage [9-11]. Nostalgia and pilgrimage are connected in sports literature in such a way that tourists travel in order to visit or see the most famous sport venues and locations, such as Roland Garros, museums, personalities, historical moments of their football teams, or even to participate in mythic marathons such as the one in New York.

Sport not only creates its own heritage, myths, and pilgrimage paths based on physical places, but also through experiences or personal challenges. In the case of outdoor trails, there is also the additional fact of running in a natural and emblematic, sometimes even protected, environment, which must be respected according to the rules of ITRA [4]. 
Table 1. Number of trails by year [4].

\begin{tabular}{cc}
\hline Year & Number of Trails \\
\hline 2000 & 1 \\
2001 & 1 \\
2002 & 4 \\
2003 & 6 \\
2004 & 9 \\
2005 & 12 \\
2006 & 16 \\
2007 & 142 \\
2008 & 169 \\
2009 & 231 \\
2010 & 317 \\
2011 & 420 \\
2012 & 561 \\
2013 & 699 \\
2014 & 857 \\
2015 & 1047 \\
2016 & 1433 \\
2017 & 1787 \\
2018 & 2217 \\
2019 & 2513 \\
\hline
\end{tabular}

The case of the Penyagolosa Trails has some differentiating facts. First, the race was born as a consequence of the struggle of a group of mountain runners who sought to maintain and recover the ancestral paths of this area, unlike other sport events where the governments and territorial officials use the event as an instrument of local development. Second, the race follows the same route as the pilgrimage known as the Peregrins de les Useres, who began their journey to the sanctuary of Sant Joan de Penyagolosa (Castellón, Spain) in the fifteenth century.

The objective of this case of study is to present and describe the cohabitation of two different kinds of tourism events that take place in the Penyagolosa Natural Park: a sport tourism event, the Penyagolosa Trails, and a historical one, the Peregrins de les Useres. This article attempts to address research gaps in the literature in order to show that the past and heritage are connected with the present in a sustainable equilibrium through a sport that produces mutual benefits thanks to the collective effort and goodwill of the interested parties.

This paper is organized as follows: Section 2 provides the conceptual framework and revises the most relevant literature on all the topics related to the paper, such as sport tourism, trail running, heritage, and pilgrimage. Section 3 focuses on the methodological approach that has been followed. Section 4 is the research context, and in Section 5 the setting and the events are described. Finally, the Discussion and the Conclusions sections summarize the main findings and limitations of the study.

\section{Conceptual Framework}

Sport has become an important branch within the tourism sector, thus giving rise to a specialised area. Sport tourism is a complex and multifaceted phenomenon existing under several forms and names [12], such as the touristification of sport or the sportification of tourism. Between $25 \%$ and $30 \%$ of the world's tourism economy is estimated to be related to sport, and a further increase is forecast in this type of tourism [13]. In the sport tourism experience, a series of interacting factors intervene, such as the activities, the participants, and the place [14]. The benefits come not only from the execution of sporting activities, but also from the tourists accompanying them.

Sport events act as powerful travel generators, since they attract tourists pursuing the various benefits that these events offer $[6,7,15]$. There are several types of sport tourists, both active and passive [14], since the sport event includes, besides the athletes (the active ones), the officials, entourage, 
suppliers, management, media, members or spectators, and VIPs [16]. As for the economic impact of sport tourism events, it may come in the form of food, accommodation, and other related expenses [17].

A sport event is a wide concept that may be classified as major or minor depending on the importance of its consequences [18]. The literature identifies four subcategories within the major section [19]. Type A events are those irregular, one-off, major international events generating significant economic activity and media interest, such as the Olympic Games or the Football World Cup; the second category, Type B, involves major spectator events generating significant economic activity and media interest, and that are part of an annual domestic cycle of sport events (e.g., FA Cup Final, Six Nations Rugby Union Internationals, or Wimbledon). Type C refers to irregular, one-off, major international spectator/competitor events generating limited economic activity (e.g., World and European championships in all sports except those previously mentioned). Finally, Type D encompasses major competitor events which generate limited economic activity and are part of an annual domestic cycle of sport events (e.g., national championships in most sports).

The phenomenon of running has become viral all over the world at a vertiginous rate. The first studies on this sport have already highlighted the positive addiction it generates [12]. Research analysing the involvement and motivation of runners has found that the key factors are not only the desire to win [20], but also the participants' physical well-being, testing one's limits [21-23], or acquiring other benefits such as an improvement to mental health and self-esteem $[21,22,24]$. There is also the social aspect of sharing the common interest with other people and liaising with peers [20,25].

Running has also found its breeding ground in a society that is attracted by the possibility of obtaining quick results and experiences the scarcity of resources (both economic and physical) to do it, or in the fact that it is a versatile sport that admits both individual and collective practice. In Spain, the data obtained from the latest survey on sports habits carried out by the Spanish Ministry of Education, Culture and Sport (MECD) reported that more than $50 \%$ of the population practises sport on a regular basis, the race being the second most practised activity [26].

Trail running is a unique experience resulting from the genuineness of the landscape and the simplicity of enjoying nature while also challenging one's mind and body. There is a market niche for trail runners who share similar preferences—-the communitas [27]—and the experiences are shaped by all the stakeholders [28]. Despite trail running being practiced by many followers, it was not until 2013 that ITRA was set up, thus laying the foundations of trail running together with a series of associated values: authenticity, humility, fair play, equity, respect and solidarity. Respect for nature intervenes in all of them [1].

However, the motivation behind trail runners has been scarcely researched [27]. The profile of the trail athlete is a young adult aged 18 to 24 , whose participation decreases as they age to 45 and older [27]. The need to disconnect from the pressures of big cities, along with the concern for leading a healthy and balanced life, has driven the search for new forms of sports practice, leading trail athletes to seek pure air and greater direct contact with nature, together with the emotions provided by the race — thrill, fear, control, skills, achievement, fitness and risk—or its social factors (friends, image, escape, competition) [16-18,27].

Natural locations not only provide some attractions for the athletes, but also for their companions and the spectators. These are lured by a host of factors such as the beautiful scenery, the originality of the place, the proximity to interesting places [13], the conviction that the mental regeneration is greater [29], the obtaining of more positive specific health and well-being outcomes [30], the conviction that mental regeneration is greater, and even the development of a more intimate link with the natural world [20,31-33]. For tourism destinations, outdoor sports can be considered as a territorial resource [34]. Against this background, there has been a proliferation of sports careers based in natural environments and in direct contact with nature. Although this kind of sport tourism competition is considered a minor sport event [35], thus generating limited economic activity, public administrators are willing to host these trails in their mountains [18]. One particularity of this small-scale sport event is that unlike in the great majority of sport competitions, it is difficult to measure the direct economic 
return for the organization, as the public does not need a ticket to access the trail [18], which has consequences when counting the number of attendees.

Organizing a sporting event in a protected area implies new management challenges regarding its sustainability. The attraction that this type of event involves goes hand in hand with the destruction of physical, economic, or sociocultural means [36]. Nowadays, national parks and conservation reserves are subject to increasing levels of recreation, sport, and tourist pressures. The environmental impacts produced are the consequences of travel, accommodation, and recreational activities [31]. Trails fulfil specific roles within the parks, so their degradation poses problems for protected areas [37]. These include damage to vegetation, soil erosion and compaction, disturbance of wildlife, water pollution, vandalism, excessive noise, track widening and braiding [31,38]. In particular, in comparison with other trail users, trail runners produce more intensive trampling impacts on the trails. Because hiking trails are designated for hikers, they may not be able to absorb impacts caused by competitive trail runners, which may be worsened by the fact that there are large numbers of runners participating in the races during very short periods of time (one or two days) [39]. To manage trails effectively, managers need to obtain timely and reliable information on trail conditions and rates of degradation $[40,41]$.

Among the mountain sport activities, a new variety has appeared which has been little studied in literature: secular pilgrimages in sacred paths for athletic rather than religious purposes. Their runners are motivated by something extra, such as the search for an authentic rural setting, and a return to origins by exploring one's own identity and lost roots. The growing economic crisis and the lack of prospects in cities have driven people in search of their rural roots. The rural milieu has been reconfigured in our postindustrial context as a reserve of identity, environment, history, heritage, and culture, where an intangible heritage associated with the values of spirituality and authenticity plays a fundamental role as territorial capital [42].

Thus, while the event is paramount, it becomes a more powerful factor in motivating travel if combined with the destination. The literature has studied the phenomenon of iconic events to refer to those which have special status or symbolic meaning within a social world or community of interest and have some kind or reputation [27], or ones whose mythic status is related to their newsworthiness as a consequence of extensive interpretation and exploitation in political arenas. The particular feature of these iconic events is that they do not have a set of attributes which defines their symbolic value, but rather this value is rated as high or low by those affiliated with the special interest, and it may derive from the size of the event, the prestige, its reputation for excellence or its uniqueness [27]. At the same time, they are important for the communitas, the holders of similar values, since they provide them with self-expression (defining who they are) and the possibility of sharing information with the rest of members of the group-the communitas [27].

\section{Methodology}

To carry out this research, we chose the qualitative methodology of the case study, since it can provide an in-depth understanding of a variety of elements, facts, and processes [43-45]. Tourism research-based case studies present a series of aspects that validate their utilization as methodological tools, which are the following [46-49]: (1) They can explain whether an innovation failed or worked. (2) They have the advantage of hindsight and can be relevant in the present or in the past. (3) They can illustrate the complexities of a situation by recognizing more than one contributing factor. (4) They show the influence of politics or personalities on the issue. (5) They show the influence of the passage of time. (6) The reader can apply them to his/her particular situation. (7) They can evaluate the alternatives that were not chosen. (8) They use information from a variety of sources. (9) They present information in a variety of ways. (10) They can illuminate a general problem through the examination of a specific instance. 
The purpose of this research was to present an illustrative descriptive case of study where tourism and neighbourhood coexist in two different events that share a protected natural area with deep historical and ancient roots, without leading to confrontations.

To do so, we chose the cases of the Penyagolosa Trails and the traditional pilgrimage of the Peregrins de les Useres, which has taken place for seven centuries in the Natural Park of Penyagolosa in the Province of Castellón, on the Mediterranean coast of Spain.

This case study was selected because through sport, tradition and ancestral paths are valued. The majority of trails are held in the mountains through paths that are open to them, but in this case, the race is done on an existing trail, with historical roots, the path of peregrination leading to the sanctuary of Penyagolosa. In addition, Penyagolosa Trails, with this 1000-metre-high race, has positioned itself internationally at the level of other mountain peaks such as Mont Blanc and Mount Fuji, as they are all members of the Ultra-Trail World Tour [50].

Moreover, a further differential fact was that there is a lot of literature that studies trails from different perspectives but no previous studies have been found addressing the particularities of this case, that is to say, the use of a spiritually motivated path as a mountain race.

\section{Data Collection and Analysis}

Data collection consisted of the following stages. First, there was a revision of the literature that allowed the researchers to identify the most important aspects arising from the organization and managing of both events, and which served as the basis for the elaboration of the interviews. In a parallel way, regarding the population distribution in the Province of Castellón, census data from different sources, namely the National Statistics Institute of Spain [51], the ITRA website [4], the Penyagolosa Trails website [52] and Ultra-Trail World Tour [50] were collected. In addition, some field work through the Ultra-Trail website was carried out.

Surveys were conducted in the form of semi-structured interviews and were held between the months of March and July of 2018 and March and July of 2019. Semi-structured interviews are associated with a qualitative methodology and they have a flexible list of focus points that allows the interviewer to adapt the conversation. There is some reciprocity between the interviewer and the interlocutor, who, at the same time, may adopt the roles of informer and even co-researcher. The stance of the researcher is subjective and his/her perspective is insider or emic. In these semi-structured interviews, data are collected with field notes and transcription recordings. The bases of analysis are textual and the findings are expressed as depth and thick descriptions. Finally, narrative is the most common reporting style [47,48].

In this case, the series of interviews was conducted with three separate entities: first, the sponsoring foundation, Fundación Trinidad Alfonso; second, the manager of Penyagolosa Trails, Mr Vicente Cervera and the marketing department of the same organization; and, finally the Provincial Government (Diputación de Castelló), being represented by Mr Luis Martínez, Provincial Deputy of Sports, and Ms Ester Felip, Director of the Cabinet.

The previous list of things gathered by the interviewers to focus the interview included the following information. The sponsoring foundation was questioned about its role in the managing of the sport event. As for the organizers of Penyagolosa Trails, they were asked about data such as the history, evolution, number of participants, objectives, environmental impact, internationalization, competitors, institutional support, local sustainability, and media followers. Finally, the representatives of the provincial government provided the interviewers with information regarding factual data about the province and sport, Castellón as a sport arena, their supporting role for the race, the importance of the race at a local level, the impact on locals, any kind of environmental disruption, and the political strategies for the local government.

The data were assessed separately by three researchers who participated in the research. From that analysis, conclusions were drawn to present each case. 


\section{Research Context}

\section{The Province of Castellón (Spain)}

Castellón is a province located on the Mediterranean coast, in the northern part of the Valencian Community (Spain), and on the western side of the province is the mountainous Sistema Ibérico. The economy of the province of Castellón is based mainly on the production of citrus fruits, agriculture, and the ceramics industry. Although the highest peak in the province of Castellón is Sant Joan de Penyagolosa, with a height of 1814 metres, Castellón is the second most mountainous province in Spain, and enjoys the additional attraction of being close to the Mediterranean sea. This is well-known by the mountaineers, the local government, and the inhabitants of the area, who have had to reinvent themselves by focusing on mountain tourism, with a real equilibrium between natural, environmental, sustainable activities in the mountains, mountain sports, entrepreneurship, and local initiatives to develop local economies [53].

The province has 135 villages and had a total of 576,898 inhabitants in 2018 [51,54]. There are notable differences among its towns. As Figure 3 shows, the most densely populated areas are on the coastline. Table 2 shows the numbers of villages in the province grouped by number of inhabitants.

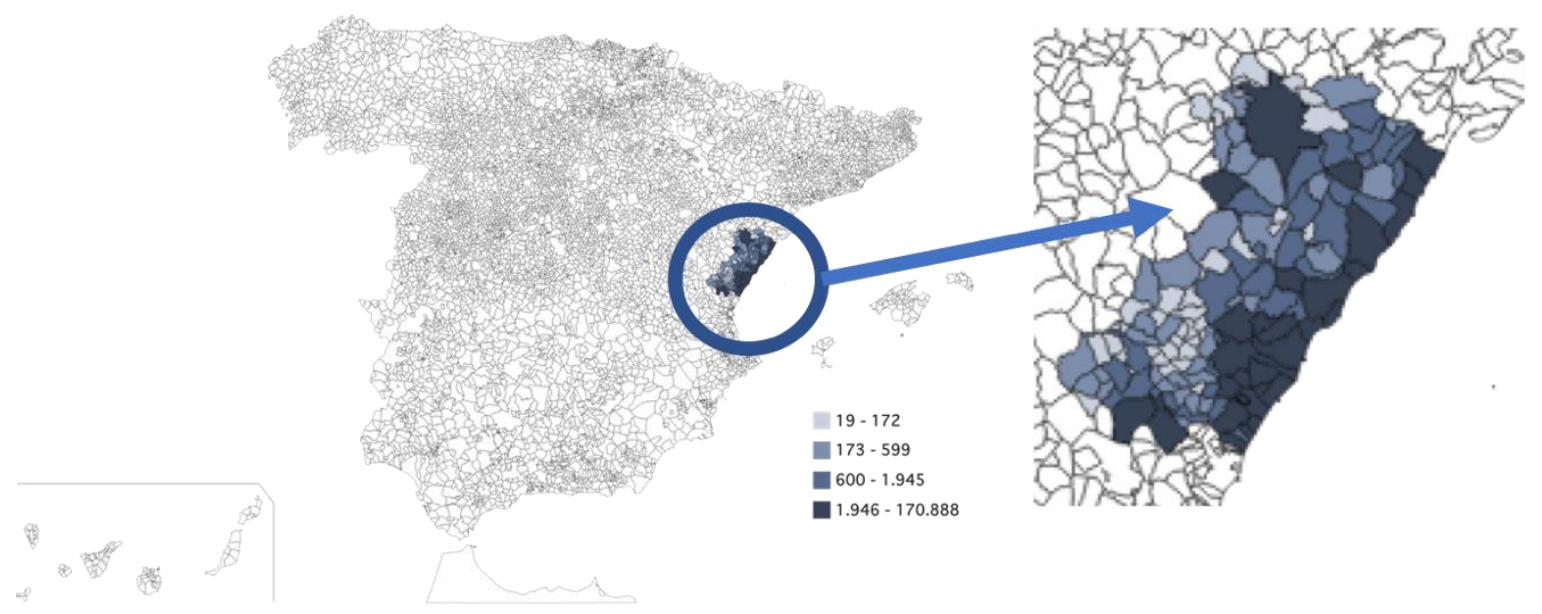

Figure 3. Distribution of population in the province of Castellón (Spain) [51].

Table 2. Numbers of villages ranked by inhabitants [51].

\begin{tabular}{cc}
\hline Number of Inhabitants & Number of Towns \\
\hline 6500 & 120 \\
13,000 & 5 \\
19,500 & 2 \\
26,000 & 2 \\
32,500 & 3 \\
39,000 & 1 \\
45,500 & 0 \\
52,000 & 1 \\
171,000 & 1 \\
\hline
\end{tabular}

The most populous city is Castellón de la Plana, the capital of the province, located on the seacoast with 170,888 inhabitants, representing $29.62 \%$ of the total population. A total of $38.57 \%$ of the population from the province live in seven small villages, making a total of 222,536 inhabitants. Figure 3 above shows the dispersion of the population in the west and the concentration in the east, near the seaside. The rest of the population is spread around small inland localities. These small villages have traditionally been dedicated to agriculture and livestock, although in recent years they have found an important source of income in rural tourism [51,55]. 
As it happens in any other rural areas in Europe, the villages in the inner area of Castellón have experienced strong emigration in the late nineteenth and during the twentieth centuries from the countryside to the urban areas or the nearest big villages $[33,54,56,57]$. These migratory flows, along with the climatology, territorial and geographical difficulties have reduced their economic opportunities. Using rural tourism as a tool of sustainable development has provided them with the opportunity to revitalize the area and prevent depopulation [58,59].

\section{The Events: Els Peregrins de les Useres and the Penyagolosa Trails}

\subsection{Els Peregrins de les Useres (The Pilgrims of Useras)}

In Spain, one of the oldest pilgrimages is Els Peregrins de les Useres (The Pilgrims of Useres) [60,61], in the Natural Park of Penyagolosa in the Valencian Community. As a natural reserve, the park is a space whose purpose is the protection of ecosystems or particularly fragile or important biological elements, prioritizing their conservation over any type of use. Therefore, human activities are very restricted in their use and management plans. The creation of the natural park system in Spain derived from the establishment of autonomous communities, and the movement was encouraged by decision makers in the capital cities of the regions so as to protect their nearest nature, thus responding to the demanding requirements of urban environmental conservation groups $[57,62]$, but also seeking the enhancement of the public's use and their enjoyment of these areas. The distinction of natural park is awarded at a regional level and there are 131 throughout the Spanish geography. Among the 22 natural parks located in the Valencian Community, the Penyagolosa Natural Park enjoys a special symbolism for all the Valencians because of the Penyagolosa mountain, but also owing to its rich landscape and culture [63].

Despite the fact that its origin is not clear, the celebration of Els Peregrins de les Useres dates back to the fourteenth century, when the inhabitants of this village made a vow: each year, on the last Friday of April, 13 pilgrims representing the entire town would be sent to the sanctuary of San Joan de Penyagolosa. Figure 4 shows photographs taken during the pilgrimage. They travel the 35 kilometres up to this sacred place and back, wearing habits and accompanied by rites, songs, and ceremonies, with the objective of asking for rain, health, and peace. The procession is made up of 12 pilgrims, a clear resemblance to Jesus and the Apostles, along with a guide, followed by a group of singers, cooks, and transporters, and hundreds of spectators. The Penyagolosa massif, also known as The Sacred Mountain [64], or El Gegant de Pedra (the Stone Giant) to the villagers, has been since time immemorial a destination for prayers and pilgrimages $[60,65]$.
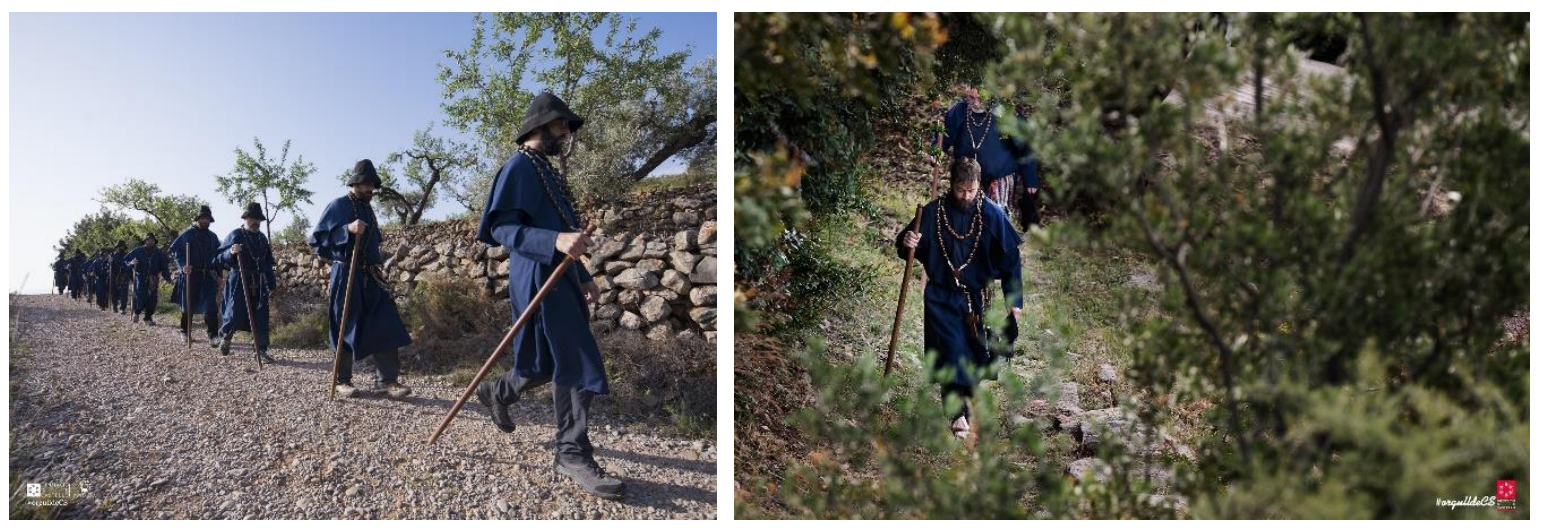

Figure 4. Els Pelegrins de les Useres $[60,65]$.

With the passing of the years, the event has become a very important tourist resource due to its marked ascetic and community character [61,66], its magic and beauty, but also because of two important facts: the path that links the small village of Useres with San Joan de Penyagolosa was 
declared a natural monument by the autonomous government in 2007, and the pilgrimage itself was declared intangible cultural property in 2016.

Pilgrimages represent an excellent element of attraction for both pilgrims and tourists. Pilgrimages provide the added differentiating value of the authentic, which is a plus, as opposed to the artificial [53]. Authenticity is a key element in this sacred journey $[67,68]$, which has given rise to the concept of rural sociability: the paradox that participants enjoy contact with nature but are also inevitably in contact with others [62]. This hiking-oriented pilgrimages, which are sport events and activities taking place either wholly or partly on historical pilgrimage routes, but for athletic rather than spiritual purposes [62]. On the other hand, there is also the feeling of identity and of belonging to an original community [66], of recovering our origins in the rural sphere, which we all have hidden and relegated as we are now part of urban society [62]. These traditions are no longer exclusive to the local identity, but rather have become part of the collective heritage [69].

\subsection{Penyagolosa Trails. History and Evolution}

The Penyagolosa massif is part of the ancestral history of the whole province. This peak, the Stone Giant, is located in the village of Vistabella del Maestrat, with 342 inhabitants, which is crowned by the sanctuary of Sant Joan.

In this emblematic context, the Penyagolosa Trails arises. Under this name, two prestigious mountain races are collected: Marató i Mitja (hereafter MiM) and Castelló-Penyagolosa (hereafter CSP).

The story of this event goes back to the 1950s, when a group of local mountaineers and hikers decided to recover the tradition of climbing to the sanctuary of Sant Joan de Penyagolosa, starting from the city of Castellón. This challenge brought together a project to restore ancient roads and trails, and resulted in the Sender de la Lluna Plena (the Full Moon Trail), known by the name of GR-33 [52,70]. GR is the acronym for the long-distance footpaths in Europe. The network is maintained in Spain by the Spanish Federation for Mountain and Climbing Sports (hereafter FEDME) [70].

This idea was born among a group of friends and began to enjoy a reputation among the local mountaineers, first, at an individual level, and later, among the different mountain clubs in the province, whose members meet year after year to climb and participate in the race to Sant Joan de Penyagolosa.

It was in 1996 that local mountain clubs decided to co-organize the trail Pujada a Peu Castelló-Sant Joan de Penyagolosa using the ancient pilgrimage route, but it was not until 1999 that the first official trail as it is known today, the MiM, took place.

In 2003, the Sport Association Marató i Mitja Castelló-Penyagolosa was selected to host the Second Mountain Racing Championship of Spain of the FEDME [70], and in 2008, the Spanish individual and team championships (Gran Premio Buff Salomon) [70].

Since then, the MiM has been a 60-kilometre tour and goes through the localities of Castellón, Borriol, Useres, Torrosselles, Xodos, and Sant Joan. Table 3 shows the numbers of inhabitants in these villages. In New York City alone there are more than 8.5 million inhabitants and the New York marathon runners numbered around 52,000 in its 2018 edition. These 52,000 runners may not affect the rhythm of the city, but when 1500 participants cross villages that are between 5 and 13 times smaller than the number of people going through them, impact is obviously higher [71,72].

Table 3. Number of inhabitants in the villages that MIM goes through [51].

\begin{tabular}{cc}
\hline Village & Number of Inhabitants \\
\hline Vistabella del Maestrat & 342 \\
Chodos/Xodos & 113 \\
Llucena/Lucena del Cid (Torroselles) & 1319 \\
Useras/Useres, les & 966 \\
Borriol & 5322 \\
Castellón de la Plana/Castelló de la Plana & 170,888 \\
\hline
\end{tabular}


The last MiM edition, in April 2019, was the twenty-first. Due to the high demand of runners, four years ago the organization decided to limit the number of athletes to 1500 for each edition due to environmental reasons, in order to encourage integration with the environment and so as not to hinder the locals [52].

Furthermore, at the beginning of the 2000s, the organization and the provincial government had begun to work together with the economic strategic plan for the province in order to implement ways by which tourism and sports would be the drivers of economic development in the inner communities, thus helping to prevent depopulation and preserve the historical and natural heritage of the province. This intervention by the provincial government proved to be decisive for the Penyagolosa Trails.

Eight years later, as a result of this collaboration, the association and the provincial government decided to extend the race from the 60 kilometres of the MiM to the 109 kilometres of the CSP. The objective of this change was to increase the relevance of the race by making it go through a greater number of villages, as shown in Table 4 and Figure 5.

Table 4. Numbers of inhabitants in the villages that the CSP goes through [51].

\begin{tabular}{cc}
\hline Village & Inhabitants \\
\hline Castellón de la Plana/Castelló de la Plana & 170,888 \\
Borriol & 5322 \\
Vilafamés & 1833 \\
Useras/Useres, les & 966 \\
Llucena/Lucena del Cid & 1319 \\
Atzeneta del Maestrat & 1271 \\
Chodos/Xodos & 113 \\
Culla & 504 \\
Benafigos & 149 \\
Vistabella del Maestrat & 342 \\
Villahermosa del Río & 462 \\
\hline
\end{tabular}
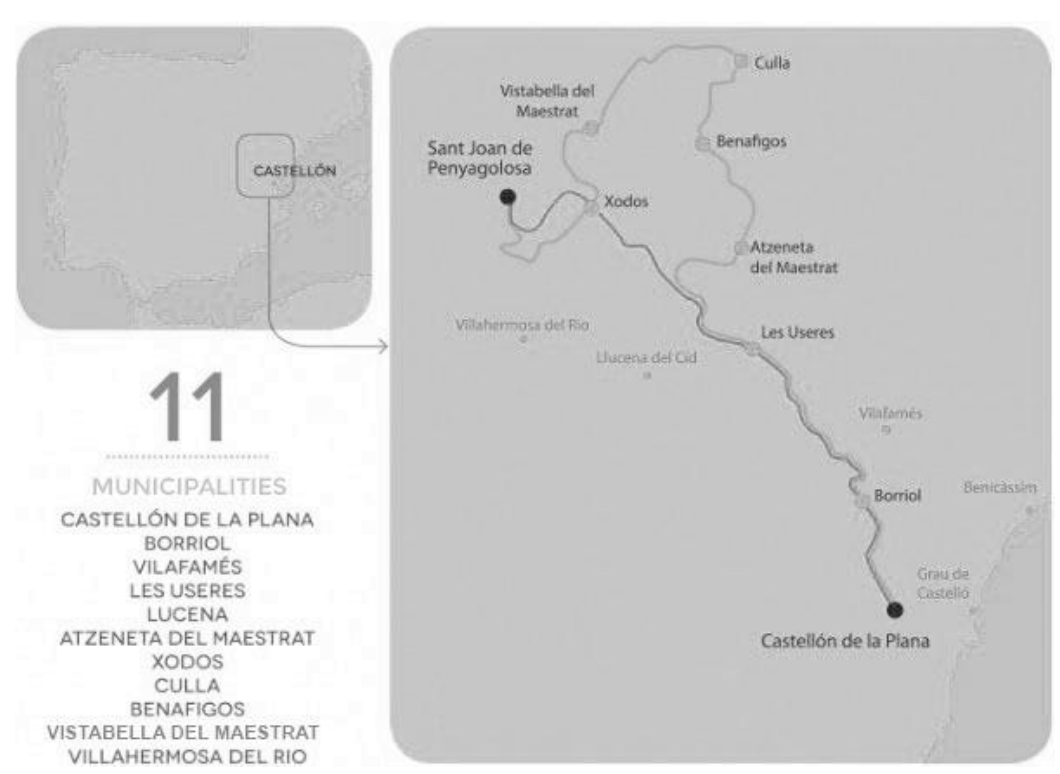

Figure 5. Total route from Castellón to the sanctuary of Sant Joan de Penyagolosa [73].

Two important landmarks put Penyagolosa Trails on the world map of mountain racing. On the one hand, and in coordination with the provincial government, the Penyagolosa CSP became part of the Ultra-Trail World Tour in 2017. One year later, in 2018, Penyagolosa Trails hosted the World Trail Championship. In their fact sheet they called for all the stakeholders' attention to absolute respect for the preservation of nature, under the motto: "Don't leave more than footprints; don't take more than pictures" [52]. In this new version of the race, the maximum number of runners was 600 [52]. 


\subsection{Ultra-Trail World Tour and Penyagolosa}

The Ultra-Trail World Tour is an international racing circuit which started in September 2013, in Chamonix (France). The eight most famous trail-running race managers decided to group together within a unique circuit in order to "share and promote the values of this sport" [74]. The idea was born in an international way and led by the Ultra Trail Mont Blanc (UTMB), a trail-running event full of superlatives, and the Marathon des Sables, the best known trail-running race. The participants in the Ultra-Trail World Tour are assured of running different trail diversities, while sharing certain common values such as ethics, sporting fairness, self-respect, and respect for the environment. Athletes discover different sporting and cultural specificities as the circuit races are held on five continents [75]. The objective of the Ultra-Trail World Tour is to establish an international trail circuit with the best over-100-kilometre races in the world.

In 2014, the final program included ten races:

1. Vibram Hong Kong 100 (China)

2. The North Face Transgrancanaria (Spain)

3. Vibram Tarawera Ultramarathon (New Zealand)

4. Marathon des Sables (Morocco)

5. Ultra-Trail Mt. Fuji (Japan)

6. The North Face 100 Australia (Australia)

7. The North Face Lavaredo Ultra-Trail (Italy)

8. The Western States 100 Mile Endurance Run (USA)

9. The North Face Ultra-Trail du Mont-Blanc (France, Italy, Switzerland)

10. La Diagonale des Fous (Reunion Island, France)

Since then, other trails have been included in this select group. In order to comply with their values in an international circuit, the races are selected following these criteria:

1. Trail-running races of at least 100 kilometres

2. Emblematic locations

3. Popular races (around 500 runners, minimum)

4. International events

5. At least two previous editions of the race

Becoming part of this select group of trails in 2017 boosted the internationalization of the Penyagolosa Trails race. Two organizations made this fact possible: on the one hand, the Provincial Government of Castellón, which supported the event from its very beginning, and on the other, the support of a private Valencian foundation, Fundación Trinidad Alfonso. The mission of this foundation is "to promote social actions that satisfy the maximum number of beneficiaries, using sport as an example and as a way to radiate the model and values of the Culture of Effort" [76], thus aligning with the intrinsic values of the Penyagolosa Trails.

The fact that Penyagolosa is a natural park, a natural monument, and an ancestral path in the history of the region with great cultural traditions in Castellón, makes its maintenance, sustainability, and respect for the traditions one of the organization's most important challenges.

Runners cross the Natural Park of Penyagolosa during the two Penyagolosa Trails HG races (the MiM and the CSP). During one day, a maximum of 2100 runners can participate in the trail. In order to reduce the environmental impact, the maximum number of athletes is 1500 in the MiM, and 600 participants in the CSP. These figures reflect the impact of the race in the natural park. The 2100 runners of both races multiply by seven the number of inhabitants of Vistabella del Maestrat, where the sanctuary of Sant Joan is located, and the total number of runners is almost 20 times the number of people living in the smallest village of the race, Xodos, which has 113 neighbours. Not only 
do the inhabitants not oppose the race, but for them the fact that the event is held in that place is a reason for pride and celebration, as reported by the Penyagolosa Trails Organization.

The participation rules have had to be modified due to the huge success of the competition and the concern about the sustainability of the event. In 2015, the participation of runners was limited as mentioned above. That year registration was opened and runners participated in strict order of registration until the quota was filled. Because this system turned out to be ineffective since it benefitted local runners, a new system was implemented a year later, which remains to this day. Thus, there is a pre-registration period that culminates with a draw before a public notary, where the 600 participants of the CSP and 1500 of the MiM are selected. Extra runners are usually allowed in the pre-registration since it is estimated that the losses prior to the race, disqualifications, and DNFs (did not finish, that is to say, runners not ending the race) will compensate for the excessive number of participants.

Applications increased in 2017, after joining the Ultra-Trail World Tour. In 2016, 560 runners took part in the MiM and 1428 in the CSP, rising to 616 and 1524 respectively in 2017. Joining the international circuit has also influenced the runner's profile. In 2015 and 2016 the profile of the runner of the CSP was mostly of Spanish nationality, and there were only around 2.5\% international runners. In 2017, the percentage rose to $5.19 \%$, reaching $15.61 \%$ in 2018 , and standing at $7.34 \%$ by 2019 , as shown in Table 5. The data have been provided by the Penyagolosa Trails Organization.

Table 5. Percentage of international runners by trail and year.

\begin{tabular}{ccc}
\hline Year & MiM & CSP \\
\hline 2015 & $1.17 \%$ & $2.18 \%$ \\
2016 & $0.98 \%$ & $2.50 \%$ \\
2017 & $2.82 \%$ & $5.19 \%$ \\
2018 & $7.19 \%$ & $15.61 \%$ \\
2019 & $2.64 \%$ & $7.34 \%$ \\
\hline
\end{tabular}

One of the biggest showcases of the race is through social networks, since before the world championship the Penyagolosa Trails HG had 17,000 followers on Facebook, 3600 on Instagram, and 3500 on Twitter. After the 2018 edition, the number of followers increased by $30 \%$ on Facebook, $110 \%$ on Instagram, and 35\% on Twitter. This effect was increased by what could be called the "Timothy Olson effect" [77,78]. Olson, an American runner who is highly active on social media and has numerous ultra-running wins, shared his training and running experiences in Penyagolosa with his 35,600 followers, as reported in Figure 6. 


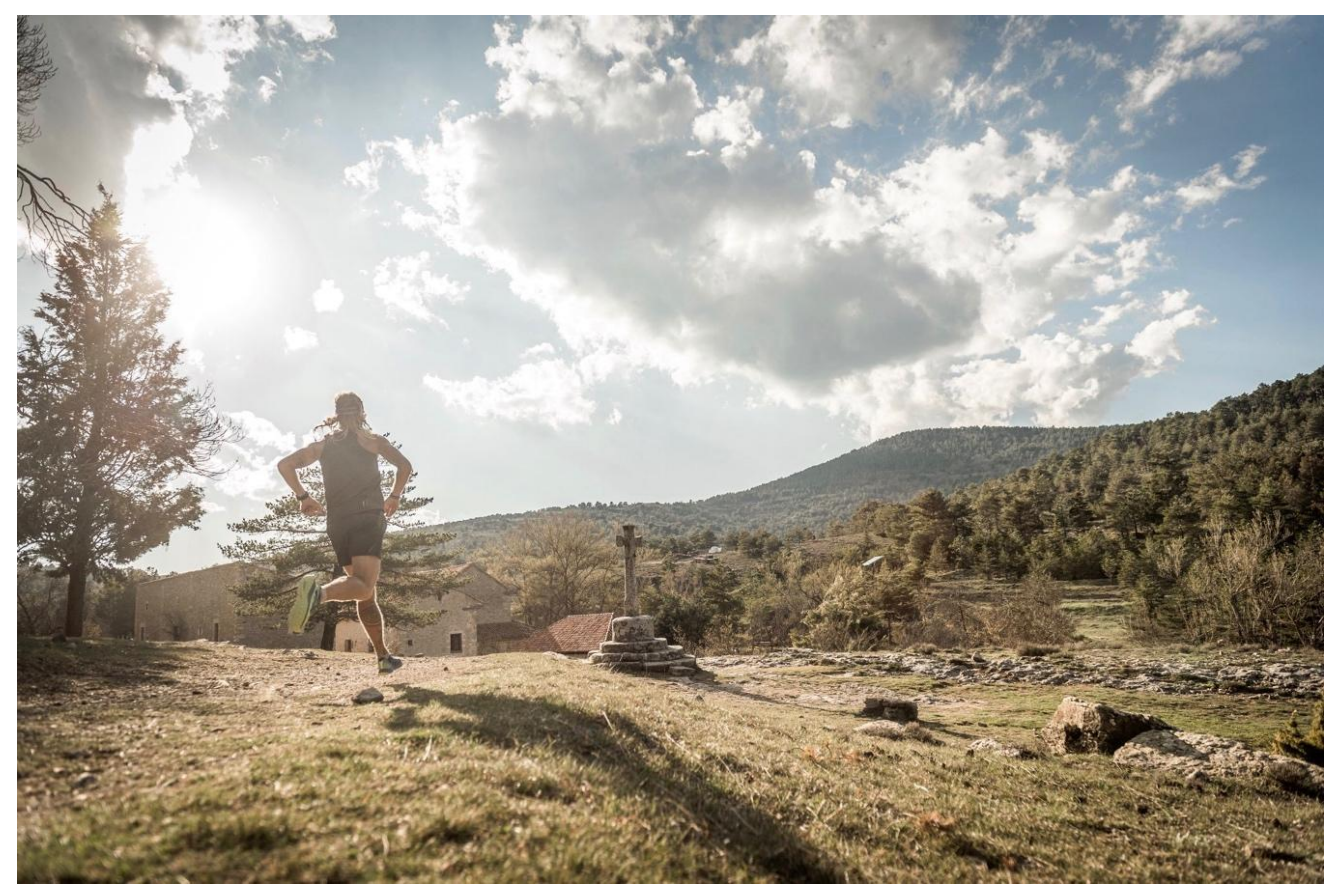

Figure 6. Timothy Olson running in the Sant Joan de Penyagolosa sanctuary $[77,78]$.

\section{Discussion}

The fact that Penyagolosa is a natural park, a natural monument, and an ancestral path in the history of the region with a great cultural tradition in Castellón, makes its maintenance, sustainability, and respect for the traditions one of the organization's most important challenges.

Organizing trail events may have important consequences for the local tourism, in fact, unlike the major sport tourism events, these events can be considered as a form of sustainable tourism [4] in terms of the economic and social implications that derive from the direct and indirect impacts on the local community.

Runners cross the Natural Park of Penyagolosa during the two Penyagolosa Trails HG races (the MiM and the CSP). As there is no specific regulation for sport activities in Spanish national parks, the implementation of policies and values to preserve the areas is at the discretion of the organization, despite the general lack of prohibitions regarding the organization of sport activities [63,79]. However, some sport institutions that are directly involved in these kinds of events, such as FEDME, issue a series of guidelines providing strategies and advice when it comes to managing a sport event in a natural park [70].

During one day, 2100 runners can participate in the trail. This figure gives an idea of the impact of the race in the natural park, as the number of participants in both races is seven times the number of inhabitants of Vistabella del Maestrat, where the sanctuary of Sant Joan is located, and the total number of runners is almost 20 times the number of people living in the smallest village of the tour, Xodos, which has 113 neighbours. However, the so-called small events may have more positive repercussions on the host community than the mega ones [80]. In fact, regional events may surpass the larger events in the level of authenticity and indigeneity of the experience [81]. While traditionally the organization of these types of events in natural parks may entail some kind of confrontation [82], in these particular cases, not only do the inhabitants not oppose the race, but for them the fact that the event is held in that place is a reason for pride and celebration, as reported by one of the managers of the trail.

The Penyagolosa Trails coexists with the surrounding environment, which is why it must be scheduled on the calendar so as not to conflict with all the pilgrimages, since every village around the park has its own peregrination that enjoys preference over the sporting event. The number of people willing to participate is so high that negotiations must be made among the local towns so as not to 
coincide on the day and thus avoid disturbing each other [62]. In the rest of the races, the objective is to reach the finish line, while the runners of the Penyagolosa culminate their feat with the arrival at the sanctuary of Penyagolosa, thus adding an extra spiritual factor for the athlete.

In order to reach the objective of sustainability, a number of actions have been implemented. On the one hand, the Organization of the Penyagolosa Trails was given the Certificate of Conformance to ISO 20121, to prove that the sport event meets the requirements of the standard regarding all financial, economic, social, and environmental issues relevant to its operations [83]. The two-way relationship between sport and tourism and sustainability must be understood while including the ethical perspective so that their impacts on the external environment can be more effectively managed [84].

On the other hand, some local policies have been implemented so as to ensure the maintenance of the natural environment and minimise the possible environmental impact in favour of the conservation of the park. Last April 2019, the autonomous Department of Agriculture, Environment, Climate Change and Rural Development signed a protocol of actions with the Organization of the Penyagolosa Trails with the aim to properly integrate the trails within the framework of the management of the Penyagolosa Natural Park and the natural monument of the Peregrins de les Useres. The document aims to maintain a path of dialogue and collaboration to improve the environmental integration of the races, extending as far as possible the measures of design, development, and evaluation with the objective of avoiding any significant environmental effect, but also to act as a platform for training and dissemination of the environmental values of the area among practitioners of mountain sports $[58,63]$. Not in vain, the organization estimates that the last edition of the Penyagolosa Trails HG would generate income in the province of 1,125,000 euros, compared to the million euros of impact accounted for last year [85].

Thus, the rural area is revitalized with the economic benefits of the event, in the forms of participants, followers, media coverage, etc. As for the organization of the race, the choice of such an emblematic place earned them international recognition to become part of the Ultra-Trail races. The athletes compete in an exclusive scenario that brings them closer to the core values associated with the practice of trail running. At the same time, they experience a mental regeneration as they tread ancestral routes laden with spiritual sentiment. In addition to direct economic effects on the area, the event can boost the visibility and attractiveness of both the mountain area $[18,86]$ and the path of the Peregrins de les Useres. One of the objectives of the local government is to have the Peregrins de les Useres declared Intangible Cultural Heritage by the UNESCO [87].

\section{Conclusions}

This paper presents the successful cohabitation of two totally opposed events, thus allowing a look back into the past but bringing light to the sustainable future of the region.

At a local level, the facts that the initial idea of the Penyagolosa Trails came from the local people, who inevitably are highly committed to the care of their environment, and that at a later stage the event sought support from the institutions, rather than being a case of the institutions leading the project, have been some of the determining factors behind the success of this collaborative project. These facts were subsequently reinforced with international recognition in the form of the organization of competitions and its selection to become part of the prestigious Ultra-Trail World Tour.

Research from existing literature on the damage caused by trail runners in natural parks highlights the importance, among other things, of rejecting the application of large-scale running events on sensitive trails. Recommendations include the use of sustainable trails which are used for foot traffic [39]. In this case, the fact that the race uses the same path as the pilgrimage ensures that no extra trails are going to be opened.

Other factors leading to the peaceful integration of both events are careful planning by all the stakeholders and negotiations between all the parties, in such a way that every small village in the Natural Park of Penyagolosa is ensured a day to do its pilgrimage, but giving it some space for the 
celebration of the international trail race. The support of the regional and local authorities, together with a private foundation, has made possible the coexistence of both events, thus seeming to support the idea that on the one hand, it is possible to make a small-sized sport event sustainable for the host community, and on the other, that these local events may exceed larger ones regarding their authenticity and the indigeneity of the experience. Furthermore, previous studies on the revitalization of rural areas $[54,88]$ have supported the key role that local people have in the successful implementation of plans, as they value a series of factors such as good leadership skills by the managers in combination with the spirit of community, corporatism, and goodwill by the stakeholders.

The case of study presented in this paper has to be seen in light of some limitations, mainly regarding the generality of its findings. One of the limits was the difficulty to extrapolate the results with respect to other territories and cases.

First, the fact that the Penyagolosa Trails is a sport event in the mountains made it difficult to quantify the economic impact, as we had only information about the participants, but the spectators in loco do not pay to attend the event, so that involved an extra issue when it came to differentiating the real sport tourists from the general tourists [18]. As it is a citizens' initiative that began 20 years ago, historical data were not computerized, which sometimes made it difficult to access them. Furthermore, the small size of the localities in the natural park explains the scarcity of economic data or the difficulties in recovering them.

More research is necessary in order to find out the real impact of the sport event on the host community. Future studies should collect data regarding the increase in accommodations or event-related expenditures, in line with some previous studies existing in the field [17,25,86].

Moreover, it would be interesting to find out the information from the reports resulting from the newly implemented local policies about the environmental impact of the event, following some previous research on this topic $[40,41]$

There are few studies that address the topic of sport events as tools for local development in inland areas. In fact, the United Nations World Tourism Organization (UNWTO) has recently published a monograph with a near topic: Walking Tourism-Promoting Regional Development [89,90], which may help to arouse the interest of academic economists in this area.

So far, the literature has shown a disproportion on most of the factors involved in the management of a trail event (sustainability, opportunities for development, running, impact, etc.). However, the factors involved in the successful cohabitation of two so diametrically opposed events-a religious and a sport event sharing the same trails-is an under-researched area.

For further research, a regression analysis could be done to study the economic determinants of the trail in the area and analyse the economic effect on participants' expenditures at the destination, the implications to tourism development, and their possible effects as leverage against depopulation.

Author Contributions: Conceptualization-R.C.M. and M.E.-B., methodology-D.B.-C., interviews-M.E.-B., investigation-D.B.-C., R.C.M. and M.E.-B., literature review-R.C.M., data curation-R.C.M. and M.E.-B., writing-original draft preparation-R.C.M. and M.E.-B., writing-review and editing-D.B.-C., R.C.M. and M.E.-B., supervision-D.B.-C., project administration M.E.-B.

Funding: This research received no external funding.

Acknowledgments: This work has been funded in part by the Universidad Católica de Valencia San Vicente Mártir. This research was carried out thanks to the participation of the Penyagolosa Trails Organization and its General Manager Vicente Cervera. The authors would like to thank Luis Martínez, Provincial Deputy of Sports (2015-2019) and Ester Felip, Director of the Cabinet (2015-2019) and Fundacion Trinidad Alfonso. Heartfelt thanks are due to Carla Tena from the Marketing Department of Penyagolosa Trails for her support and for providing the official statistics of the trail.

Conflicts of Interest: The authors declare no conflict of interest. 


\section{Abbreviations}

$\begin{array}{ll}\text { CSP } & \text { Castelló-Penyagolosa } \\ \text { DNF } & \text { Did not finish } \\ \text { FEDME } & \text { Spanish Federation of Mountain and Climbing Sports } \\ \text { GR } & \text { Acronym for the long-distance footpaths in Europe } \\ \text { ITRA } & \text { International Trail Running Association } \\ \text { MECD } & \text { Spanish Ministry of Education, Culture and Sport } \\ \text { MiM } & \text { Marató i Mitja Race } \\ \text { UNEP } & \text { United Nations Environment Programme } \\ \text { UNESCO } & \text { United Nations Educational Scientific and cultural Organization } \\ \text { UNWTO } & \text { United Nations World Tourism Organization } \\ \text { VIP } & \text { Very Important Person } \\ \text { WTO } & \text { World Tourism Organization }\end{array}$

\section{References}

1. Discover Trail-Running_ITRA. Available online: https://itra.run/page/259/Definition_of_trail-running.html (accessed on 5 November 2019).

2. Krein, K.J. Nature Sports. J. Philos. Sport 2014, 41, 193-208. [CrossRef]

3. Hodeck, A.; Wohlfart, O. Characterising sport tourists based on motivation-the case of the SachsenTrail 2017 (Germany). Available online: https://www.researchgate.net/profile/Alexander_Hodeck/publication/ 326266142_Comparing_two_types_of_nature_sport_event_tourists_in_Germany_based_on_travel_ motivation_and_behavior-_the_case_of_ski_tourers_vs_trail_runners/links/5bcf0fec92851c1816ba7a48/ Comparing-two-types-of-nature-sport-event-tourists-in-Germany-based-on-travel-motivation-andbehavior-the-case-of-ski-tourers-vs-trail-runners.pdf (accessed on 21 November 2019).

4. ITRA. Available online: https://itra.run/community/ (accessed on 14 October 2019).

5. Torbidoni, E.I.F.; Seguí Urbaneja, J.; Inglés Yuba, E. Profiling participants of sporting events in the natural environment: Trails running races. In Sustainable Development of Sports Tourism; Annales University Press: Koper, Slovenia, 2015; pp. 185-194.

6. Ramshaw, G. Sport, heritage, and tourism. J. Herit. Tour. 2014, 9, 191-196. [CrossRef]

7. Ramshaw, G.; Gammon, S. More than just Nostalgia? Exploring the heritage/sport tourism Nexus. J. Sport Tour. 2005, 10, 229-241. [CrossRef]

8. Centre, U.W.H. World Heritage. Available online: https://whc.unesco.org/en/about/ (accessed on 3 November 2019).

9. Ritchie, B.W.; Adair, D. Sport Tourism: Interrelationships, Impacts and Issues; Channel View Publications: Clevedon, UK; BufFalo, NY, USA, 2004; ISBN 978-1-873150-65-8.

10. O'Connor, P. Handrails, steps and curbs: Sacred places and secular pilgrimage in skateboarding. Sport Soc. 2018, 21, 1651-1668. [CrossRef]

11. Cusack, C.M.; Digance, J. The Melbourne Cup: Australian Identity and Secular Pilgrimage. Available online: https://www.taylorfrancis.com/ (accessed on 5 November 2019).

12. Bourdeau, P.; Corneloup, J.; Mao, P. Adventure Sports and Tourism in the French Mountains: Dynamics of Change and Challenges for Sustainable Development. Curr. Issues Tour. 2002, 5, 22-32. [CrossRef]

13. Hoye, R.; Parent, M.M. The SAGE Handbook of Sport Management; SAGE: Thousand Oaks, CA, USA, 2016; ISBN 978-1-4739-5923-1.

14. Getz, D. Event tourism: Definition, evolution, and research. Tour. Manag. 2008, 29, 403-428. [CrossRef]

15. Hinch, T.; Ramshaw, G. Heritage sport tourism in Canada. Tour. Geogr. 2014, 16, 237-251. [CrossRef]

16. Masterman, G. Strategic Sports Event Management; Routledge: Abingdon, Oxon, 2014.

17. Daniels, M.J.; Norman, W.C. Estimating the Economic Impacts of Seven Regular Sport Tourism Events. J. Sport Tour. 2003, 8, 214-222. [CrossRef]

18. Duglio, S.; Beltramo, R. Estimating the Economic Impacts of a Small-Scale Sport Tourism Event: The Case of the Italo-Swiss Mountain Trail CollonTrek. Sustainability 2017, 9, 343. [CrossRef]

19. Gratton, C.; Dobson, N.; Shibli, S. The economic importance of major sports events: A case-study of six events. Manag. Leis. 2000, 5, 17-28. [CrossRef] 
20. Ogles, B.M.; Masters, K.S. Older vs. younger adult male marathon runners: Participative motives and training habits. J. Sport Behav. 2000, 23, 130-143.

21. Bond, K.A.; Batey, J. Running for Their Lives: A Qualitative Analysis of the Exercise Experience of Female Recreational Runners. Women Sport Phys. Act. J. 2005, 14, 69-82. [CrossRef]

22. LaChausse, R.G. Motives of Competitive and Non-Competitive Cyclists. J. Sport Behav. Mob. 2006, 29, 304-314.

23. McCarville, R. From a Fall in the Mall to a Run in the Sun: One Journey to Ironman Triathlon. Leis. Sci. 2007, 29, 159-173. [CrossRef]

24. Conboy, J.K. The Effects of Exercise Withdrawal on Mood States in Runners. J. Sport Behav. 1994, 17, 188.

25. Lamont, M.; Kennelly, M. A Qualitative Exploration of Participant Motives among Committed Amateur Triathletes. Leis. Sci. 2012, 34, 236-255. [CrossRef]

26. Anuario de Estadísticas Deportivas. Available online: http://www.culturaydeporte.gob.es/servicios-alciudadano/estadisticas/deportes/anuario-de-estadisticas-deportivas.html (accessed on 13 October 2019).

27. Getz, D.; McConnell, A. Comparing Trail Runners and Mountain Bikers: Motivation, Involvement, Portfolios, and Event-Tourist Careers. J. Conv. Event Tour. 2014, 15, 69-100. [CrossRef]

28. Perić, M.; Vitezić, V.; Badurina, J.Đ. Business models for active outdoor sport event tourism experiences. Tour. Manag. Perspect. 2019, 32, 100561. [CrossRef]

29. Bodin, M.; Hartig, T. Does the outdoor environment matter for psychological restoration gained through running? Psychol. Sport Exerc. 2003, 4, 141-153. [CrossRef]

30. Bowler, D.E.; Buyung-Ali, L.M.; Knight, T.M.; Pullin, A.S. A systematic review of evidence for the added benefits to health of exposure to natural environments. BMC Public Health 2010, 10, 456. [CrossRef]

31. Gammon, S.; Robinson, T. Sport and Tourism: A Conceptual Framework. J. Sport Tour. 2003, 8, 21-26. [CrossRef]

32. Brymer, E.; Downey, G.; Gray, T. Extreme Sports as a Precursor to Environmental Sustainability. J. Sport Tour. 2009, 14, 193-204. [CrossRef]

33. Cavaco, C. Rural Tourism: The Creation of New Tourist Spaces. Eur. Tour. Reg. Spaces Restruct. 1995, $127-149$.

34. Falaix, L. Les sports de nature dans le département des Landes: Du développement maîtrisé à la mobilisation d'une «ressource territoriale». Ann. Geogr. 2012, 686, 410-432. [CrossRef]

35. Wilson, R. The economic impact of local sport events: Significant, limited or otherwise? A case study of four swimming events. Manag. Leis. 2006, 11, 57-70. [CrossRef]

36. Malchrowicz-Mośko, E.; Botiková, Z.; Poczta, J. “Because We Don't Want to Run in Smog": Problems with the Sustainable Management of Sport Event Tourism in Protected Areas (A Case Study of National Parks in Poland and Slovakia). Sustainability 2019, 11, 325. [CrossRef]

37. Hawes, M.; Candy, S.; Dixon, G. A method for surveying the condition of extensive walking track systems. Landsc. Urban Plan. 2006, 78, 275-287. [CrossRef]

38. Leung, Y.F.; Marion, J.L. Trail degradation as influenced by environmental factors: A state-of-the-knowledge review. J. Soil Water Conserv. 1996, 51, 130-136.

39. Ng, S.L.; Leung, Y.F.; Cheung, S.Y.; Fang, W. Land degradation effects initiated by trail running events in an urban protected area of Hong Kong. Land Degrad. Dev. 2018, 29, 422-432. [CrossRef]

40. Cole, D.N. Impacts of hiking and camping on soils and vegetation: A review. Environ. Impacts Ecotourism 2004, 41, 60.

41. Marion, J.L.; Leung, Y.F. Indicators and protocols for monitoring impacts of formal and informal trails in protected areas. J. Tour. Leis. 2011, 17, 215-236.

42. Camarero Rioja, L.A.; Bardají De Azcárate, I.; Oliveira Baptista, F. X Coloquio Ibérico de Estudios Rurales; Editorial Universitat Politècnica de València: Valencia, Spain, 2014; ISBN 978-84-9048-285-8.

43. Stake, R.E. The Art of Case Study Research; SAGE: Thousand Oaks, CA, USA, 1995.

44. Yin, R.K. Case Study Research: Design and Methods; Sage: Thousand Oaks, CA, USA, 2009.

45. Botella-Carrubi, M.D.; González-Cruz, T.F. Context as a Provider of Key Resources for Succession: A Case Study of Sustainable Family Firms. Sustainability 2019, 11, 1873. [CrossRef]

46. Beeton, $\mathrm{S}$. The case study in tourism research: A multi-method case study approach. In Tourism Research Methods: Integrating Theory with Practice; CABI Publishing: Wallingford, UK, 2005; pp. 37-48.

47. Ritchie, B.W.; Burns, P.M.; Palmer, C.A. Tourism Research Methods: Integrating Theory with Practice; CABI: Wallingford, UK, 2005; ISBN 978-0-85199-996-8. 
48. Jennings, G.R. 9 Interviewing: Techniques. In Tourism Research Methods; CABI Publishing: Wallingford, UK, 2005; pp. 99-117.

49. Hoaglin, D.C.; Light, R.L.; McPeek, B.; Mosteller, F.; Stoto, M.A. Data for Decisions: Information Strategies for Policy Makers "by" David Hoaglin et al. (Book Review)_ProQuest; Abt Books: Cambridge, MA, USA, 1982.

50. History. Available online: https://www.ultratrail-worldtour.com/history/ (accessed on 15 July 2019).

51. Instituto Nacional de Estadística. (National Statistics Institute). Available online: http://www.ine.es/dynt3/ inebase/index.htm?padre $=522$ (accessed on 8 July 2019).

52. Penyagolosa Trails | About Us. Available online: http://penyagolosatrails.com/en/about-us/ (accessed on 15 July 2019).

53. Santamarina, B. El patrimonio inmaterial en el País Valenciano: Una explosión muy tangible. Revista Andaluza de Antropología 2017, 12, 117-143. [CrossRef]

54. Currás, R.; Escriva, M. Case Study: Don't Say Street Art, Just Say Fanzara. In Entrepreneurship in Culture and Creative Industries: Perspectives from Companies and Regions; FGF Studies in Small Business and Entrepreneurship; Innerhofer, E., Pechlaner, H., Borin, E., Eds.; Springer International Publishing: Cham, Switzerland, 2018; pp. 265-279. ISBN 978-3-319-65506-2.

55. Turisme Comunitat Valenciana. Available online: http://www.turisme.gva.es/opencms/opencms/turisme/es/ contents/estadistiquesdeturisme/estadistiquesdeturisme.html?tam=\&menu_id=18 (accessed on 15 October 2019).

56. Yagüe Perales, R.M. Rural tourism in Spain. Ann. Tour. Res. 2002, 29, 1101-1110. [CrossRef]

57. Shaw, G.; Williams, A.M. Critical Issues in Tourism: A Geographical Perspective; Blackwell Publishers: Hoboken, NJ, USA, 1994.

58. World Tourism Organization. Tourism and the Sustainable Development Goals - Journey to 2030; World Tourism Organization (UNWTO): Madrid, Spain, 2018; ISBN 978-92-844-1940-1.

59. Hall, D.R.; Kirkpatrick, I.; Mitchell, M. Rural Tourism and Sustainable Business; Channel View Publications: Bristol, UK, 2005; ISBN 978-1-84541-011-7.

60. Camins de Penyagolosa | Les Useres. Available online: https://caminsdepenyagolosa.dipcas.es/es/les-useres. html (accessed on 18 July 2019).

61. Los Peregrinos de Useras | Ayuntamiento de Les Useres. Available online: http://www.lesuseres.es/visitantes/ los-peregrinos-de-useras (accessed on 11 October 2019).

62. Vidal-González, P.; Sánchez, V. Hiking paths and intangible heritage: A quest for cultural roots. Cases in the province of Castellón, Spain. Sport Soc. 2018, 22, 2065-2076. [CrossRef]

63. Parques Naturales de la Comunitat Valenciana-Generalitat Valenciana. Available online: http://www. parquesnaturales.gva.es/es (accessed on 14 October 2019).

64. Webster, J. Sacred Sierra: A Year on a Spanish Mountain; Random House: New York, NY, USA, 2009.

65. Multimedia. Available online: https://caminsdepenyagolosa.dipcas.es//es/multimedia.html (accessed on 14 October 2019).

66. Monferrer i Monfort, À. Tres romiatges penitencials medievals de Castelló. Rev. Alguer 1994, 5, 55-69.

67. Santamarina Campos, B.; Moncusí Ferré, A. El mercado de la autenticidad. Las nuevas ficciones patrimoniales. Rev. Occidente 2015, 93-112.

68. Waterton, E.; Watson, S. The Palgrave Handbook of Contemporary Heritage Research; Springer: Berlin/Heidelberg, Germany, 2015; ISBN 978-1-137-29356-5.

69. Ariño Villaroya, A.; García Pilán, P. Apuntes para el estudio social de la fiesta en España. Anduli 2007, 6, 13-28.

70. FEDME—Federación Española de Deportes de Montaña y Escalada. Available online: http://www.fedme.es/ ?action=seccion. seccion\&subseccion=89 (accessed on 14 October 2019).

71. TCS New York City Marathon. Available online: https://www.nyrr.org/tcsnycmarathon (accessed on 8 November 2019).

72. New York Cities by Population. Available online: https://www.newyork-demographics.com/cities_by_ population (accessed on 8 November 2019).

73. Penyagolosa Trails | Sostenibilidad. Available online: http://penyagolosatrails.com/en/ (accessed on 10 July 2018).

74. UTMB UTMBß—A Mythical Race, an Unique Experience. Available online: https://utmbmontblanc.com/en/ page/1/Amythicalrace, an uniqueexperience.html (accessed on 17 July 2019).

75. Concept. Available online: https://www.ultratrail-worldtour.com/info/concept/ (accessed on 17 July 2019).

76. Quiénes somos • Fundación Trinidad Alfonso-Fund. Trinidad Alfonso. Available online: https:// fundaciontrinidadalfonso.org/quienes-somos/ (accessed on 8 May 2019). 
77. Olson, T. Penyagolosa Trails 115K. Timothy Allen Olson. 2017. Available online: http://www.timothyallenolson. com/2017/05/12/penyagolosa/ (accessed on 16 April 2019).

78. Olson, T.A. Looking forward to reaching this cross. Tonight we embark on @PenyagolosaTr - buena suerte! May you all have an incredible day. Available online: \#runmindfulpic.twitter.com/BkjZwCKrGD. @timmyolson_run2017T13:05 (accessed on 13 February 2019).

79. Conselleria de Agricultura, Desarrollo Rural, Emergencia Climática y Transición Ecológica - Generalitat Valenciana. Available online: http://www.agroambient.gva.es/es/inicio (accessed on 14 October 2019).

80. Joppe, M.; Veltri, G.; Shen, Y. Embedding Indigenous Learning Outcomes in a Tourism Curriculum. In Proceedings of the Tourism Travel and Research Association: Advancing Tourism Research Globally, Portland, OR, USA, 15-17 June 2015.

81. Hall, C.M. The definition and analysis of hallmark tourist events. GeoJournal 1989, 19, 263-268. [CrossRef]

82. Rech, Y.; Mounet, J.P.; Briot, M. L'innovation dans les sports de nature: L'irruption de nouvelles activités dans une station de sports d'hiver. Espac. Soc. 2009, 136, 155-171. [CrossRef]

83. Penyagolosa Trails | Environmental policy. Available online: http://penyagolosatrails.com/en/sostenibilidad/ (accessed on 15 February 2019).

84. Fyall, D.A.; Jago, L. Sustainability in Sport \& Tourism. J. Sport Tour. 2009, 14, 77-81.

85. El Penyagolosa Trails dejará en el interior de Castellón un millón de euros en un fin de semana. Available online: https:/castellonplaza.com/el-penyagolosa-trails-dejara-en-el-interior-de-castellon-unmillon-de-euros-en-un-fin-de-semana (accessed on 14 October 2019).

86. Perrin-Malterre, C. Tourism diversification process around trail running in the Pays of Allevard (Isère). J. Sport Tour. 2018, 22, 67-82. [CrossRef]

87. UNESCO. Patrimonio Mundial. Available online: https://caminsdepenyagolosa.dipcas.es//es/unescopatrimonio-mundial.html (accessed on 18 November 2019).

88. MacDonald, R.; Jolliffe, L. Cultural rural tourism: Evidence from Canada. Ann. Tour. Res. 2003, 30, 307-322. [CrossRef]

89. World Tourism Organization. Sustainable Mountain Tourism-Opportunities for Local Communities; World Tourism Organization (UNWTO), Ed.; World Tourism Organization (UNWTO): Madrid, Spain, 2018; ISBN 978-92-844-2026-1.

90. World Tourism Organization. Walking Tourism_Promoting Regional Development; World Tourism Organization (UNWTO), Ed.; World Tourism Organization (UNWTO): Madrid, Spain, 2019; ISBN 978-92-844-2034-6. 